\title{
DELIBERATIVE DEMOCRACY'S \\ ATTEMPT TO TURN POLITICS INTO LAW
}

\author{
CHRISTOPHER H. SCHROEDER*
}

I

INTRODUCTION

In the summer of 2001, President George W. Bush faced a difficult decision. He needed to articulate his administration's policy regarding federal funding of medical research on embryonic stem cells. A year earlier, the National Institutes of Health had announced guidelines to fund such research. Upon entering office, President Bush elected to review those guidelines and to make his own determination of federal policy. On August 9, 2001, he made his first primetime television address to announce his decision.

The period preceding the President's decision drew as much attention as the decision itself. President Bush reportedly studied the problem with great care, read and consulted with experts about the medical potential of such research compared to research using adult stem cells, and heard from individuals and groups concerned about the intentional destruction of human embryos as well as from others convinced that the medical benefits of such research should not be foregone. 'Several weeks before the President's final decision, his Secretary of Health and Human Services talked with Jim Lehrer of the nightly PBS news program, the News Hour.

JIM LEHRER: In a general sense is the president making-in your opinion-is the president making a scientific decision, or is he making a political decision?

TOMMY THOMPSON: I can assure you it's not a political decision-it will be a scientific and ethical decision that this president will make, will base his final decision on.

JIM LEHRER: But isn't it basically weighing the whole element of when life begins and anti-abortion ideas versus other things-all that it's not a big-

TOMMY THOMPSON: It's all of that and more. ${ }^{2}$

Copyright (c) 2002 by Christopher H. Schroeder

This article is also available at http://www.law.duke.edu/journals/65LCPSchroeder.

* Professor of Law and Public Policy Studies, Duke University.

My thanks to David Barron, Neil Kinkopf, Elena Kagan, Arthur Lupia, and Peter Schuck for valuable comments and criticism, as well as to the other participants in the conference on the Law of Politics.

1. For more details of the President's decision-making process, see infra notes 132-144 and accompanying text.

2. The News Hour with Jim Lehrer (PBS television broadcast, July 12, 2001), available at http://www.pbs. org/News Hour/bb /health/July-dec01/thompson_7-12.html. 
"Political decision [-making]" in this exchange involves calculating the electoral advantages or disadvantages to President Bush by figuring out who the winners and losers of the decision to fund stem-cell research would be, and predicting how they would react. As estimated by the public opinion polls conducted at the time, more people supported federal funding than opposed it. ${ }^{3}$ A politician's benefit-loss calculation, however, takes account of more details than these overall numbers. The composition of the groups on either side of an issue can matter a great deal. In this case, right-to-life citizens strongly opposed such funding, while medical researchers and persons standing to benefit from the medical advances promised by stem cell research earnestly supported funding. In looking over this breakdown, any adviser to President Bush could see that the opposition included a crucial re-election constituency known to vote in high percentages. It would be costly to dampen their enthusiasm for making political contributions, participating in get-out-the-vote efforts, and turning out to vote themselves. In contrast, the people committed enough to stem cell funding to make it the basis for their vote were probably less numerous, as well as less critical to the President's re-election prospects, although only time would reveal whether that prediction was accurate.

Secretary Thompson sought to dissuade Lehrer and his viewership from thinking that such a political calculation would play any role in the stem cell research decision. Most Americans were probably not convinced. ${ }^{4}$ Polling organizations often ask citizens about their perceptions of the role electoral or political considerations play in the choices their elected officials make. The results show an overwhelming belief that elected officials are "out for themselves," either by giving priority to electoral considerations or feathering their own nests in other ways. By a five-to-one ratio, for example, Americans think members of Congress work to better themselves rather than the country. ${ }^{5}$ By a $61 \%$ to $32 \%$ margin, people think it is impossible for members to avoid being influenced by the financial contributions that they receive when making policy decisions. ${ }^{6}$ They believe that government decision-making is dominated by the "special interests," groups with the ability to contribute to campaigns in amounts that individuals cannot match. ${ }^{7}$ Americans differentiate sharply between their own beliefs and those of special interests. In one poll, $82 \%$ felt that

3. See infra notes $140-143$ (describing the polling data).

4. See infra text accompanying notes $144-146$.

5. In one poll, the response rates were $74 \%$ and $17 \%$, respectively. Capitol Hill Watch: Congressional Facts and Figures, NAT'L J., Mar. 15, 1997, at 524 (discussing a Feb. 1997 Fox News Opinion Dynamics poll).

6. $I d$.

7. When asked about the power of different groups influencing policy in Washington, people respond that "big companies," "political parties," the "news media," and "political lobbyists" exert too much influence, by percentages ranging from $79 \%$ to $88 \%$. Louis Harris \& Associates Poll, Nov. 10, 1994 (results on file with the author). 
"those we elect to Congress in Washington lose touch with the people pretty quickly." Only 16\% disagreed.

Trust that government will work for the public good fluctuates in response to world or national events. In the aftermath of the terrorist attacks on the World Trade Center and the Pentagon on September 11, 2001, trust-ingovernment figures have spiked upward. ${ }^{9}$ Even the post-September 11 level of confidence was less than recorded in $1964,{ }^{10}$ however, and a review of the data over the past four decades reflects a decline in trust that began in the mid-1960s and has persisted ever since. ${ }^{11}$ Just one in five said in 1994 that they trusted Washington to "do what's right" always or most of the time. In 2000, the percentage saying this was up to $44 \%$, a height not reached since President Reagan's first term, when many such measures showed an improvement. These numbers, however, are sharply lower than in 1958, when the comparable figure was $73 \%$, or than 1964 , when it reached $76 \% .^{12}$

The public's overall disposition toward Congress was expressed well by a citizen participating in a focus group discussion about government:

Unfortunately, I think that Congress has reached a point now where ... there are so many special-interest groups that have bucks, and [members of Congress] are going to work on taking care of them. The people that make the most noise get the most attention, and those people have the money and the numbers to get it. ${ }^{13}$

The sense that our social and political system has a deficit of publicly minded discourse and motivations is widely shared by academics as well as the general public. Instead of "we" talk, politics is dominated by "I" talk. This reinforces an increasingly "fragmented society... whose members find it harder and harder to identify with their political society as a community." ${ }^{14}$ Some observers

8. ABC News Poll, Apr. 8-9, 1992, reprinted in CONGRESSIONAL RESEARCH SERVICE, PUBLIC OPINION OF CONGRESS AND ITS MEMBERS 13, tbl.5 (Sept. 17, 1993). John Hibbing and Elizabeth Theiss-Morse report the same general statistical findings- $86 \%$ state that special interest groups exert too much influence-and the same disjunction between "special interests" and the general population.

Whereas close observers of politics are likely to see interest groups as vital links between the public and the government, helping to capture and to express the diversity of the public's views, the people themselves see the situation quite differently. Interest groups, they contend, are definitely not connected with ordinary people, even remotely. Instead, the popular notion is that these special interests are completely divorced from the public interest.

John Hibbing \& Elizabeth Theiss-Morse, Congress AS THE Public ENEMY 63-64 (1995).

9. A commonly polled question asks, "how much of the time do you think you can trust the government in Washington to do what is right?" A Washington Post-ABC News poll taken after the terrorist attacks showed $64 \%$ responding either "just about always" or "most of the time" to this question. Richard Morin \& Claudia Deane, Poll: Americans' Trust in Government Grows, available at http://nationaljournal.com/members/polltrack/2001/national/01fedgovt.htm\#30.

10. In 1964, 76\% responded "just about always" or "most of the time" to the trust-in-government question quoted supra note 9, compared to 64\% after September 11, 2001. The NES Guide to Public Opinion and Electoral Behavior, National Election Studies, available at http://www.umich.edu/ nes/ nesguide/toptable/tab5a_1.htm (last visited May 7, 2002).

11. HibBing \& THEISS-MORSE, supra note 8 , at 32.

12. Trust in Government, 1958-2000, The NES Guide to Public Opinion and Electoral Behavior, available at http://www.umich.edu/ nes/nesguide/toptable/tab5a_1.htm (last visited Aug. 1, 2001).

13. HIBBING \& THEISS-MORSE, supra note 8 , at 65.

14. JeAn BethKe Elshtain, DEMOCRACY On TRial 24 (1995). 
see in society a "narrow and often mean-spirited concentration on immediate self-interest;", others diagnose the problem as a case of people "having interest solely in [themselves], or at least failing to demonstrate sufficient regard for the interests of others. ${ }^{16}$ Individual self-interest and selfishness have led to identity politics and special interest politics at the group level. To capture both the individual and collective phenomena, this paper will refer to partial interests, distinguishing the pursuit of partial interests from the pursuit of the public interest, the common good, or public reason.

Much of contemporary political theory has been a reaction to the overpursuit of partial interests in the public arena. In the realm of theory, this has been expressed in a reaction to theories of political pluralism, which portray the pursuit of partial interests as relatively benign, due to the fact that competing partial interests can act as counterweights against each other, producing reasonable public policy. ${ }^{17}$ A variety of alternatives to pluralism have flowered or have been rediscovered, including communitarianism, the civil society movement, civic republicanism, and deliberative democracy. Each shares the normative claim that the influence of partial interests on public policy should be greatly reduced, and, indeed, eliminated. A prescriptive claim comes as a corollary: Individuals should refrain from asserting their partial interests in the public forum. In this way we avoid "[t]he danger that citizens advancing claims based on interests may secure legislation that does not express a publicly justified claim, but a sectarian or factional interest." ${ }^{18}$

These reactions to the over-pursuit of partial interests have become overreactions. The dangers of excessive influence of partial interests are real, but the manner in which influential modern political theories attempt to extirpate that influence raises serious problems of its own. In developing this argument, this article focuses on the approach that deliberative democracy has taken to partial interests. $^{19}$

The theory of deliberative democracy sketches a model of politics based on models of law and legal decision-making. It aspires to turn political decisions into a form of legal decision-making. It is easy to see how this ambition responds to the widespread belief that partial interests dictate public outcomes. Among other things, it implies that the kind of electoral calculations sketched

15. William Sullivan, Reconstructing Public Philosophy 3 (1986).

16. Amy Gutmann \& Dennis Thompson, Democracy AND DisagreEMENT 19 (1996).

17. See, e.g., FRANK R. BAumgartner \& BETH L. LEECH, BASIC InTERESTS: THE IMPORTANCE OF GROUPS IN POLITICS AND IN POLITICAL SCIENCE 44-63 (1998) (summarizing the pluralism scholarship and the difficulties it confronted).

18. GERALD GAUS, JUSTIFICATORY LIBERALISM 243 (1996).

19. Of all the contemporary competitors to political pluralism, deliberative democracy is exemplary in its candid acknowledging of the ineradicable plurality of viewpoints and perspectives in our society. It thus steers clear of the problematic homogenizing assumptions of civic republicanism or communitarianism. At the same time, deliberative democracy articulates a theory of politics in which plural interests would be subordinated to the public good. Much of this article's criticism of deliberative democracy's treatment of partial interests ought to be applicable, ceteris paribus, to theories that make even less realistic assumptions. 
out above would be entirely out of bounds, and that a sound public decision would be one based on science and ethics-science to predict the consequences of possible decisions, and ethics to evaluate the relative merits of those consequences.

This legalistic vision of politics leaves much out of account, portrays an unrealistic and unattractive picture of politics, and is ultimately self-defeating, or so this paper will argue. Part II elaborates on deliberative democracy's attempt to displace politics with law. Part III exposes some of the difficulties with that attempt. Part IV returns to the impetus behind the attempt-deliberative democracy's belief that comprehensive views and partial interests should play no role in politics - and questions that belief. The role of partial interests in influencing particular political outcomes is and needs to remain endogenous to political practice itself. Politics should thus bear less resemblance to law than the deliberativists claim, and partial interests should rightly play a greater role in political decisions than the deliberativists would prefer.

\section{II}

\section{DELIBERATIVE DEMOCRACY AND THE LEGAL MODEL}

This Part draws out the elements of similarity between the model of political reasoning in deliberative democratic theory and models of legal reasoning and legal decision-making. I believe that these elements are central to many different versions of the deliberative theory, but am mindful of the fact that what deliberative democracy advocates espouse cannot be reduced to any simple set of claims. $^{20}$ Deliberative theory commands a large and growing audience, as well as an ever-expanding literature, and with that growth comes a growing number of internal disagreements. To avoid a discussion based on stitched-together pieces of diverse theories which form a composite endorsed by no one, this section will rely heavily on the version of deliberative democracy developed in the work of Amy Gutmann and Dennis Thompson. Not only is theirs one of the leading versions of deliberative theory, but other theorists adopt positions similar to theirs, as the discussion and references will attest. ${ }^{21}$

The theory of deliberative democracy has been preoccupied with how democratic societies ought to deal with the fact that citizens often bring to bear

20. For conceptions of deliberative democracy more minimalist than those discussed here, see James Fearon, Deliberation as Discussion, in DeliBERATIVE DEMOCRACY 44, 44-45 (Jon Elster ed., 1998) (stating that deliberative democracy simply involves discussion before voting) [hereinafter Deliberative Democracy]; Susan Stokes, Pathologies of Deliberation in Deliberative Democracy, in DELIBERATIVE DEMOCRACY, supra, at 123 (explaining that deliberative democracy involves discussion and communication designed to change people's preferences before voting). For discussion of some of the major themes in the deliberative democracy literature, see Samuel Freeman, Deliberative Democracy: A Sympathetic Comment, 29 PHIL. \& PUB. AFF. 371 (2000).

21. The characteristics sketched out in Part II of this paper show the presuppositions of deliberative democracy that lead the theory to embrace the project of turning politics into law. The criticisms of that project remain generally applicable to variants of deliberative theory that do not share these characteristics if those variants still embrace that project, because the major criticisms of the project do not depend upon the motivations for adopting it. 
"conflicting perspectives on fundamental values" when debating what laws should govern us all. This question assumes central importance for deliberative democrats because they assume that our society is characterized by a "reasonable pluralism." 22 Persons subscribe to a "diversity of reasonable comprehensive religious, philosophical, and moral doctrines found in modern democratic societies," a condition that "is not a mere historical [one] that may soon pass away." ${ }^{23}$ Scarcity, limited generosity, incompatible values, and incomplete understanding create "irreducibl[e] moral conflict in politics." 24

A reasonable pluralism of comprehensive views promises to generate disagreement over government policies to such an extent that many of even "our most important judgments [will] be made under conditions where it is not to be expected that conscientious persons ... will all arrive at the same conclusion." ${ }^{25}$ Consequently, if any one of us is able to succeed in having his or her comprehensive view enacted into law, the result will be that the oppressive power of the state will impose a policy on some citizens that they have not chosen, because it conflicts with their own system of beliefs and values. While such a result accords with what we consider right and just, from the perspective of such others our insisting on the result seems simply to "insist on [our] own beliefs when [we] have the political power to do so." ${ }^{26}$

When is the use of state power justifiable in the face of such reasonable disagreement? The commitment of deliberativists to the liberal principle of the free and equal status of all individuals produces a distinctive answer. If, "by nature, every individual is free and equal to every other individual," then there is no essential difference between them that can justify the domination of one over the other. ${ }^{27}$ Under that view, allowing inessential characteristics such as economic or social position to determine political advantage could not be justified

22. JOHN RAWLS, POLITICAL LiBERALISM 36 (1996) [hereinafter RAwLS, POLITICAL Liberalism]. See also Joshua Cohen, Procedure and Substance in Deliberative Democracy, in DEMOCRACY AND DIFFERENCE 96, 97 (Seyla Benhabib ed., 1996) (describing "the fact of reasonable pluralism" as "the fact that there are distinct, incompatible understandings of value, each one reasonable, to which people are drawn under favorable conditions for the exercise of their practical reason"); Joshua Cohen, Moral Pluralism and Political Consensus, in THE IDEA OF DEMOCRACY 270, 281-82 (David Copp et al. eds., 1993) ("The idea of reasonable pluralism is that there are distinct understandings of value, each of which is fully reasonable. An understanding of value is fully reasonable just in case its adherents are stably disposed to affirm it as they acquire new information and subject it to critical reflection.").

23. RAWLS, POLITICAL LIBERALISM, supra note 22, at 36.

24. GUTMANN \& THOMPSON, supra note 16, at 25. John Rawls explains the existence of reasonable pluralism in a similar way. People's views are pluralistic because the relevant evidence is "conflicting and complex, and thus hard to assess and evaluate"; the weights to be assigned relevant factors are not uniformly shared; critical concepts are "vague and subject to hard cases," necessitating resort to judgment and interpretation; people's assessment of evidence and weighing of moral and political values are affected by their total life experiences, which differ; and normative considerations of different force can point in opposite directions with respect to some issues, without any definitive method for resolving which to follow. RAWLS, POLITICAL LIBERALISM, supra note 22, at 56-58.

25. RAWLS, POLITICAL LIBERALISM, supra note 22, at 58.

26. Id. at 61 .

27. Bernard Manin, On Legitimacy and Political Deliberation, 15 POL. THEORY 338, 340 (1987). 
to each individual. ${ }^{28}$ In order to be justified, the use of political power ought ideally to come from the free choices that individuals make. For deliberativists, the use of political power can be justified "if and only if [the decision] could be the object of a free and reasoned agreement among equals." ${ }^{29}$ The conditions under which such an agreement could be achieved exist if everyone accepts-or could accept—a collective decision as justified. "Political decisions are collectively binding, and they should therefore be justifiable, as far as possible, to everyone bound by them." ${ }^{31}$ Uses of political power should be choice-sensitive and status-insensitive.

Deliberativists contend that collectively binding decisions cannot be justified to free and equal individuals if they depend upon partial interests, comprehensive religious views or other sorts of ultimate commitments that any individual cannot accept, because deciding on such a basis denies equal status to each individual's opinion and comprehensive view. Thus, John Rawls states a conclusion commonly reached by deliberativists:

[C]itizens as free and equal have an equal share in the corporate political and coercive power of the society . . . . There is no reason, then, why any citizen, or association of citizens, should have the right to use the state's police power to decide constitutional essentials or basic questions of justice as that person's, or that association's, comprehensive doctrine directs. ${ }^{32}$

The situation is rendered more complex by the fact that deliberativists concede that some comprehensive views are reasonable, and hence not capable of being ruled out of hand, "even though we could not seriously entertain them for ourselves, as we think they give excessive weight to some values and fail to allow for the significance of others. ${ }^{\text {"33 }}$ Given this fact, some disagreements about how to proceed collectively will simply prove intractable. ${ }^{34}$ So how can decisions be made that are justifiable even to those who disagree with them?

Predictably, deliberativists argue that a particular type of deliberation ought to take place. An initial aim of deliberation is to achieve as much consensus as possible, but deliberativists have already conceded that disagreement on the actual decision will often persist in an environment of reasonable pluralism. Conceding the practical impossibility of consensual or unanimous decision-making, deliberative democrats shift their focus to examining how free and equal indi-

28. Joshua Cohen, Deliberation and Democratic Legitimacy, in THE GoOD POLITY 17, 19 (Alan Hamlin \& Philip Petit eds., 1989). The modern locus classicus for this argument is JOHN RAWLS, A THEORY OF JUSTICE (1971).

29. Cohen, supra note 28 , at 21.

30. The distinction between actual and hypothetical consent can be significant, but not with respect to any of the arguments developed here.

31. GUTMANN \& THOMPSON, supra note 16 , at 13.

32. RAWLS, POLITICAL LIBERALISM, supra note 22, at 61-62.

33. Id. at 59-60.

34. See, e.g., Gerald Postema, Public Practical Reason: Political Practice, in THEORY AND PRACTICE: NOMOS XXXVII 345, 355 (Ian Shapiro \& Judith Wagner DeCew eds., 1995) (noting the "challenge posed by the pervasive moral disagreement that seems characteristic of modern moral communities, and the apparent impotence of debate to achieve reconciliation"). 
viduals can achieve the most desirable kind of disagreement. ${ }^{35}$ Cut off from any assurance of unanimity, deliberative democrats articulate a process of public deliberation through which democratic decisions can be justified.

It is at this point that deliberativists' heavy reliance on the model of law and legal deliberation come clearly into view. ${ }^{36}$ Often the analogy is drawn quite explicitly. John Rawls, for example, takes the Supreme Court as the "exemplar" of the sort of "public reason" that ought to govern the public arena. Gutmann and Thompson also draw a direct parallel between the idealized decision-making of judicial actors ${ }^{38}$ and the decision-making deliberative democracy requires of political actors, rejecting the idea that pluralist interest-based bargaining ought to typify the political arena. They contend that

[d]eliberative democracy . . . calls into question the contrast between the principled decisionmaking of courts and the prudential lawmaking of legislatures in which a judge seeks to 'give meaning to our constitutional values . . . perhaps even [is] force[d] to be objective-not to express his preferences or personal beliefs, or those of the citizenry, as to what is right or just[,] . . . [whereas] [1] egislatures . . . see their primary function in terms of registering the actual, occurrent preferences of the people-what they want and what they believe should be done.' This contrast is problematic both empirically and normatively. ${ }^{39}$

35. Gutmann and Thompson are explicit about this: "[Deliberation] is offered as the morally optimal basis on which citizens who disagree about moralities and religions can act collectively. . . Recognizing that politics cannot be purged of moral conflict, it seeks a common view on how citizens should publicly deliberate when they fundamentally disagree." GUTMANN \& THOMPSON, supra note 16, at 67, 93.

36. What counts as legal deliberation or legal reasoning is itself no less heavily contested than what counts as deliberative democracy. Rather than articulate a full theory of legal reasoning, this paper identifies three basic elements that it takes as central to most such theories. See infra text accompanying notes 44-68.

37. John Rawls, The Idea of Public Reason, in DeliBerative Democracy 108-44 (James Bohman \& William Rehg eds., 1997) [hereinafter Rawls, The Idea of Public Reason]. For Rawls, the scope of public reason is limited to questions of justice as applied to "society's basic structure of institutions," and thus would not extend to many issues debated in day-to-day politics. Id. at 93. See also RAWLS, POLITICAL LIBERALISM, supra note 22, at 214-15. Many deliberative democrats, however, do not place this limitation on the scope of public reason. Amy Gutmann and Dennis Thompson, for example, argue that their version of public reason extends beyond foundational principles to "the ongoing processes of everyday politics - in[to] middle democracy." GUTMANN \& THOMPSON, supra note 16, at 40. "If moral arguments are essential to justify the foundations and results of democracy," they ask, "why should they also not be essential within the on-going processes of democracy?" Id. There are passages in Rawls intimating that he is sympathetic to efforts to extend the jurisdiction of public reason to middle democracy, and he limits his discussion of it to basic questions of justice largely to take up first "the strongest case where the political questions concern the most fundamental matters. If we should not honor the limits of public reason here, it would seem we need not honor them anywhere. Should they hold here, we can then proceed to other cases. Still, I grant that it is usually highly desirable to settle political questions by invoking the values of public reason." Rawls, The Idea of Public Reason, supra, at 95 .

38. "The fact that [the judicial deliberative] process is imperfect ... is not thought to be a reason to diminish the role of deliberation. On the contrary, the failures of moral argument in the judicial process are rightly thought to make the quest for successes all the more important." GUTMANN \& THOMPSON, supra note 16, at 45.

39. Id. (quoting Owen Fiss, Foreword: The Forms of Justice, 93 HARv. L. REv. 1, 10 (1979)). See also GAUS, supra note 18, at 263-67 (disputing as inaccurate the "bifurcation of legislative politics as the arena of interests and judicial politics as the forum of principle .... Legislative politics not only can be, but often [have] been, a fundamental part of the practice of liberal citizens to publicly justify their principled demands on each other."); STEPHEN MACEDO, LIBERAL VIRTUES 113-17 (1991). 
Gerald Gaus also stresses the identity of law and what politics should aspire to be. He argues that the need to provide "public justification" for government action leads to an "umpire account of political authority," a "juridical" model of "adjudicatory democracy" in which political decision-makers function as judges to adjudicate conflicting claims in a manner that conforms to the "rule of law."

As part and parcel of the analogy between politics and law, ${ }^{41}$ deliberative theory generates a set of expectations as to how political actors are to behave that have direct parallels to the expectations of the Anglo-Saxon legal tradition for the behavior of legal actors, although these expectations take shape within distinctive institutional frameworks. The most notable institutional distinction between law and politics is law's sharp separation of the functions of advocating and judging, while politics allows the two functions to be performed by the same individuals. Our adversary system finds much merit in the distinctive and separate functions of judge and advocate. The legal system assigns overlapping but not identical norms of conduct to persons who perform one function or the other. In contrast, our political system contains no separation of functions. Elected officials, for example, frequently perform both roles. The legalistic conception of politics struggles with the internal tensions this produces.

The political problems created by combining advocacy and judging have long been apparent. No less an authority on American politics than Publius highlighted the conflict between "competing parties [with] hostile pretensions" and the "umpire or common judge" that ought ideally to be interposed between them. ${ }^{42}$ The Federalist No. 10 frames the inherent conflict:

No man is allowed to be a judge in his own cause, because his interest would certainly bias his judgment, and, not improbably, corrupt his integrity. With equal, nay with greater reason, a body of men are unfit to be both judges and parties at the same time; yet what are many of the most important acts of legislation, but so many judicial determinations, not indeed concerning the rights of single persons, but concerning the rights of large bodies of citizens? ? $^{43}$

The Federalist No. 10 articulates the problem that deliberative theory attempts to cure, namely the ability of partial interests to influence how the coercive force of the state is used. One way to solve this problem in politics might be to draw a sharp distinction between the rulers and the ruled, but such a distinction is democratically unacceptable. Democracy, after all, is rule by the people-the same people who petition the government for policy action are necessarily involved in making the decisions. Another approach might be to impose judge-

40. GAUS, supra note 18, at 195-214 (setting forth requirements for the just use of state power in a chapter entitled "The Rule of Law").

41. The affinity between deliberative democracy and the rule of law should not be surprising. The stress deliberativists place on the normative significance of choice by free and equal persons is a point of emphasis shared with the liberal philosophical tradition of contractarian theories of politics. Such liberal theories "promise to decide a wide range of controversies fairly through decisions based on established, known, impartially applied rules and procedures - to provide, in short, the rule of law. The very notion of government as originating in a 'contract' already gives liberal political theory a legalistic cast.” ROGERS M. SMITH, LIBERALISM AND AMERICAN CONSTITUTIONAL LAW 32-33 (1990).

42. The Federalist No. 7, at 38 (Jacob E. Cooke ed., 1961).

43. THE FEDERALIST No. 10, at 59. 
like obligations on those who participate in democratic decision-making. This is the chosen path for deliberative democrats.

To convert politics to law, deliberativists develop a model of political reasoning that adapts three central elements of legal reasoning and decisionmaking. The first element is that justice is blind. Litigants stand before the bench equal in the eyes of the law, in that their cases are to be judged by legal standards that do not depend upon status, wealth, or political influence. The crowning achievement of the Anglo-American legal system in the seventeenth century was making status-insensitivity a central ideal and commitment, one that is often approximated in our legal system, albeit imperfectly. ${ }^{44}$ It is now taken for granted that a system of law "ought to ignore the social status of individuals and also to ignore their political role, unless their ability to perform that role itself requires some legal exemption." ${ }^{45}$ In effect, "the legal system ... ought to be selectively blind and ignore irrelevant facts about people." 46

Deliberative democracy aspires to replicate this equality-creating blindness in politics. Individuals should have no advantages in the process of public deliberation by virtue of their wealth, social status, ability to mobilize electoral assets, or capacity to provide rewards to other participants in the process. Instead, what ought to count in the process of deliberation is the strength of the arguments that an individual makes.

A second central element of law is its reliance on reasons. Law aspires to decision-making on the basis of reasoned argument. Once the influences of status and power have been outlawed, the remaining bases for decisions come down to reason or random selection. The law endorses reason over chance. In the judicial system, reasoned argument comes into play in two different ways. ${ }^{47}$ First, litigants advance their claims for relief by articulating reasons, orally and in writing, that relief is warranted. Second, decision-makers make the decision and then defend it publicly on the basis of reason. ${ }^{48}$

44. For a selective rendition of the story of this accomplishment, see DON HERZOG, HAPPY SLAVES 110-47 (1989).

45. Id. at 132 .

46. Id. at 126 .

47. The deliberativists who explicitly invoke the law analogy for politics take multi-member appellate bodies, especially the Supreme Court, as their model.

48. Gutmann and Thompson insist that deliberation must be a shared social practice, and criticize Rawls for espousing a more solitary understanding.

If [democratic citizens] are to weigh the interests of others and to guide their actions by a sense of justice ... then democratic societies must encourage the give-and-take of moral argument about the substance of controversial political issues ... Forums for deliberation should abound.... If we are to increase our chances of resolving our moral disagreements, we must not check our deliberative dispositions at the door to the public forum.

GUTMANN \& THOMPSON, supra note 16, at 37-38. Whatever the merits of the criticisms Gutmann and Thompson make of Rawls on this score, those criticisms can only be directed at the early Rawls, the Rawls of Theory of Justice, and not at the later Political Liberalism Rawls. As he develops the idea of public reason in this and later work, Rawls describes a system in which citizens "offer one another" public reasons for their views." Rawls, The Idea of Public Reason, supra note 37, at 116. "The point of the ideal of public reason," he now writes, is to order the terms and conditions under which "citizens are to conduct their fundamental discussions." Id. at 104. 
In the hands of deliberativists, the element of reasoned argument generates some stringent demands on political discourse. One of these constrains people to advance reasons that are sincere. Arguments must not be advanced merely for strategic purposes, as when a politician broadcasts allegations of disloyalty or scandal against an opponent without believing the allegations to be true or germane to the question of eligibility to serve in office. Instead, for a deliberative citizen to advance an argument, the argument must be one that she endorses, as well as one that "would figure prominently amongst [her] reasons for the proposal," absent other considerations. ${ }^{49}$ Reasons advanced in public must also be reasons that a citizen holds "for reasons of morality, not (only) for reasons of political advantage." ${ }^{50}$ This constraint on political participants is far tougher than anything insisted on for lawyers, and in fact would be uncomfortably confining for many advocates at law. While lawyers are under obligations not to deceive the court with respect to facts, we do not require them "to espouse only [legal] positions [that they would continue to hold] independently of the circumstances in which they speak." ${ }^{51}$ To the contrary, lawyers are under an obligation to their clients to advance the best arguments for their clients' cases, whether or not they would otherwise endorse such arguments. ${ }^{52}$

When sincere deliberation confronts an issue upon which consensus cannot be reached, deliberators bear a further obligation related to the giving of reasons: They bear an affirmative obligation to engage in "reiterated deliberation." ${ }^{, 3}$ As Gutmann and Thompson explain, "[r]eiterated deliberation encourages public officials to learn from their mistakes and to correct them. It enables citizens to hold their representatives accountable for making better decisions in the future." ${ }^{54}$

The third element of the legal model that deliberativists adopt is the most crucial. "The heart of the law lies in its structure, in the way in which it makes certain matters relevant, in the way in which it gives arguments relative importance." 55 When disputes move from unabridged public discussion into the courtroom, the law imposes structure on them in terms of the arguments that

49. Postema, supra note 34, at 358. The proviso is designed to cover cases of overdetermination. The reason articulated need not be the one that actually motivates the speaker, so long as it would be a motivating reason if no others presented themselves. Id. See also GUTMANN \& THOMPSON, supra note 16, at 126 ("the constraint [of deliberative democracy] probably does rule out making arguments that one would not accept if others made them.").

50. GUTMANN \& THOMPSON, supra note 16 , at 81 .

51. $I d$.

52. Of course, lawyers have as refined an ability to rationalize as anyone else, which often helps them to believe the arguments they make for clients are the best ones, all things considered, to be applied to the case. See Christopher H. Schroeder, Causes of the Recent Turn in Constitutional Interpretation, 51 DUKE L. J. 307 (2001) (discussing the theory of motivated reasoning as applied to legal argumentation). It nonetheless remains the case that lawyers begin researching a client's problem with a view to finding the best arguments for that client's position.

53. GUTMANN \& THOMPSON, supra note 16, at 144.

54. Id.

55. Todd Rakoff, Brock v. Roadway Express, Inc. and the New Law of Regulatory Due Process, 1987 SUP. CT. REV. 157, 164 (1987). 
are considered relevant to the case. The structure imposed is often itself the object of dispute, as each of the opposing sides asserts "theories of the case" that seek to impose a favorable structure on the dispute. In Bush v. Gore, for example, the theory of the case before the Florida Supreme Court was that the Court could exercise its usual power of judicial review to interpret statutes containing apparently conflicting rules about whether recounted ballots can, may, or must be tabulated in the final vote. ${ }^{56}$ This theory favored the Gore campaign. On the other hand, the theory of the case might have been that the Florida legislature exercised the exclusive authority vested in it under Article II of the Constitution to provide for the selection of electors so as to take advantage of federal law's "safe harbor," as the United States Supreme Court intimated it should have been. That theory of the case favored the Bush campaign.

In litigation, some of this structuring process goes on prior to trial in the practice of dispositive and non-dispositive motions, such as motions for complete or partial summary judgment; in appellate practice, however, the theory of the case is articulated definitively only when the court announces its decision and renders an opinion. In the written opinion, the court states its conclusions and articulates the reasoning justifying them. The argument over the appropriate theory of the case will itself have been structured, albeit loosely, by virtue of the fact that only certain types of arguments are recognized as constitutional and statutory arguments. ${ }^{57}$ What Governor Jeb Bush might have asserted in press conferences to be the proper result, for instance, counts for nothing.

The relevance of facts is heavily determined by how the law structures a dispute. Those of us old enough to remember the trial of the Chicago Seven for conspiracy to incite a riot at the 1968 Democratic Convention in Chicago will recognize in that trial a dramatic illustration of law's structuring effects. ${ }^{58}$ The defendants disagreed over strategy. Tom Hayden and others wanted to accept the prosecution's structuring of the case as an ordinary conspiracy trial and to concentrate on exposing its weak factual points. Others, including Jerry Rubin and Abbie Hoffman, wanted to use the trial as a stage to attract other young people to the anti-war movement by making statements about the war's evil nature and the federal government's corrupt behavior in Vietnam. Judge Julius Hoffman considered the efforts of the defendants to pursue this second objective to be disruptive and irrelevant to the trial. Judge Hoffman's intemperate efforts to keep the trial within the structure of the law of conspiracy-culminating in Bobby Seale sitting in the courtroom bound and gagged-ultimately resulted in his removal from presiding in Seale's subsequent trial on charges of criminal contempt. On the issue of relevancy, though, Judge Hoffman was cor-

56. 531 U.S. 98 (2000).

57. For one typology, see PhILIP BobBitT, CONSTITUTIONAL INTERPRETATION (1991).

58. For those of us not old enough to remember, some background is available on Doug Linder's Famous Trials web page, at http://www.law.umkc.edu/faculty/projects/ftrials/Chicago7/chicago7.html (last visited May 7, 2002). 
rect: The facts some of the defendants wished to introduce were irrelevant to the structure the law of conspiracy imposed on their trial.

In the realm of political decision-making, deliberative theory imposes considerable structure. Arguments are to be limited to those that are publicly accessible, independent of a comprehensive view that others could reasonably reject, and are not to be predicated on partial interests. ${ }^{59}$ Many deliberative theories give a little ground on these constraints when addressing what is permissible at early stages in political deliberation. Persons enjoy some liberty early on to try out arguments founded on partial interests or excluded comprehensive views. Gutmann and Thompson, for example, allow that "even extreme nondeliberative methods [i.e., speech that does not satisfy the constraints of deliberation] may be justified as necessary steps to deliberation." ${ }^{60}$ Equally clear, however, is that, prior to final decision, participants must filter out such arguments. As Rawls explains, "[such reasoning] may be introduced in public deliberation at any time, provided that in due course public reasons, given by a reasonable political conception, are presented sufficient to support whatever the comprehensive doctrines are introduced to support. ${ }^{\prime 61}$

Filtering can occur in the course of the deliberations, as the arguments raised in public debate are subjected to critical scrutiny by others. Counterarguments raised by co-deliberators may result in modifications to an original stance, as one comes to see that it does not conform to the demands of public reason. Or, self-reflection and restraint may filter unacceptable reasons. However the filtering is done, eventually "political debate [must be] organized around alternative conceptions of the public good." ${ }^{2}$ Proposals must be predicated on principles and rationales that other citizens committed to finding grounds for agreement could also endorse as a fair basis for cooperation. Any empirical claims upon which those proposals depend must flow from "relatively reliable methods of inquiry." ${ }^{63}$ By the end of the process, "proposals and the rationales for them must be both accessible to each member of the community and assessable by each member." ${ }^{64}$

Thus, deliberative democracy requires that each participant monitor and scrutinize her own positions and arguments. Arguments advanced in the public arena as ultimate bases for public action must be ones the participant endorses, relying only upon arguments and evidence that the participant sincerely believes could be adopted by all other participants sharing her commitment to the public good. Conclusions regarding public actions "should be reach[ed] through reason rather than force, and more specifically, through reasoning

59. See infra note 62 and accompanying text.

60. GUTMANN \& THOMPSON, supra note 16 , at 135.

61. Rawls, The Idea of Public Reason, supra note 37, at 135. This represents a revision of Rawls' earlier views, which were more restrictive of what arguments could be advanced in public discussion. $I d$.

62. Joshua Cohen, Deliberation and Democratic Legitimacy, supra note 28, at 18.

63. GUTMANN \& THOMPSON, supra note 16, at 55-56.

64. Postema, supra note 34, at 358-59. 
rather than self-interested bargaining." ${ }^{65}$ A policy based on "the interests of others" should not be imposed on anyone else. ${ }^{66}$ Any decision "based on the private or idiosyncratic concerns of officials" is "arbitrary" ${ }^{\prime 67}$ and unjustifiable. "[P]ublic explanations and justifications of laws and policies [must be made] in terms of conceptions of the public good."

Public reason also imposes a requirement of generality on reasons and principles. Generality requires that, when a speaker or writer endorses an argument, she commits to its application in all other situations that are relevantly similar. Generality has a direct analogue in the legal model, where courts should not advance rationales that are "good for this day and train only." Court in Bush v. Gore wrote that "[o]ur consideration is limited to the present circumstances, for the problem of equal protection in election processes generally presents many complexities," thereby at least hinting that its rationale would have no further application. ${ }^{70}$ If this is what that passage means, it transgresses the normal expectations of judicial reasoning. Deliberative rationales and arguments in political reasoning are likewise expected to be general. ${ }^{71}$

Even when such "robustly public discourse"" occurs, we already know that agreement will not always be forthcoming-just as in law, judges can disagree after both sides have been excellently briefed and superbly argued. At this point, though, the demands of public reasoning diverge from the legal model. In law, judges who have deliberated and yet continue to disagree form themselves into majorities, pluralities, concurrences, and dissents. In separate opinions, judges develop the divergent reasoning of their separate positions. Deliberative democracy is more demanding. The mutual respect which each free and equal individual owes to others implies that disagreeing deliberators are constrained to seek grounds for mutual accommodation. "Insofar as moral reasoning in politics succeeds in finding ... principles [that can be justified on the basis of mutually acceptable reasons], the conclusions of deliberation become mutually justifiable. Insofar as it fails, [deliberative democracy] continues to make demands on citizens. It prescribes accommodation based on mutual respect." ${ }^{\prime 4}$

65. Amy Gutmann \& Dennis Thompson, Moral Conflict and Political Consensus, 101 ETHICs 64, 77 (1990).

66. GAUS, supra note 18, at 232.

67. Id. at 199 .

68. Id. at 18 .

69. Smith v. Allwright, 321 U.S. 649, 669 (1944).

70. 531 U.S. 98, 109 (2000).

71. GUTMANN \& THOMPSON, supra note 16 , at 13.

72. Political discourse is robustly public "when reasonable people, mutually committed to this project [of reaching agreement or consensus] and submitting to its discipline, engage together in articulation, deliberation and argument about the structure and duty of their common life." Postema, supra note 34 , at 356 .

73. Mutual respect is the attribute that makes the entire deliberative process work. GUTMANN \& THOMPSON, supra note 16, at 79 (recognizing mutual respect as a "value ... at the core of reciprocity and deliberation in a democracy ... mak[ing] possible cooperation on fair terms").

74. GUTMANN \& THOMPSON, supra note 16 , at 56. 
The foregoing sketch brings out the manner in which the deliberative model of politics adapts critical elements of the legal model. Politics is to be blind to economic status, class, and power. Individuals participating in politics are to endorse reasoned arguments that are general in scope, and to do so sincerely. Reasons are not to be based on private interests, sectarian comprehensive views, or factual claims resting on unreliable or inaccessible empirical methods. Arguments are limited to those that others similarly committed to the project of reaching fair terms of agreement could reasonably accept. Public actions must rest on such arguments and reasons.

These principles have somewhat different formulations in the work of different deliberativists, but the project of converting politics into law lies at the heart of most of that work. Deliberative theorists want the norms of deliberation to constrain political reasoning in the same fashion as the analogous norms imposed by law constrain legal reasoning. The next section explores several reasons why the practices of politics and law do not have the similarities in structure that deliberative democracy wishes to create, and why the project of turning politics into law runs aground on the differences between them.

III

\section{The VALUes of Non-Deliberative PRACTICES}

The ambition of deliberative democracy to structure or constrain politics does not by itself distinguish deliberative theory from a number of other approaches to politics. The character of the constraints deliberative democracy seeks to impose does distinguish it, however. Think of politics as a practice comprised of inputs, decision processes, and outputs: Inputs consist of the preferences and beliefs of participants; decision processes consist of the institutions and practices that the participants employ, including practices that may transform the inputs prior to final decision; and outputs consist of the decisions generated by those institutions and practices. With this simple construct, deliberative democracy can be distinguished from prominent alternative theories by virtue of what aspects of the political system each seeks to structure.

Constitutionalism is one alternative to deliberative democracy. Constitutionalism structures the outputs of the political process by proscribing those outputs that would violate protected rights. ${ }^{75}$ One of constitutionalism's virtues is that it envisions a practice that seems capable of actually being achieved, depending upon the specific content of the protected rights. America's own society, for instance, already counts non-discrimination, fair trials, and free speech rights as well established legal constraints. Criticism of our failures to protect those rights in some circumstances carries a weight and seriousness that can ex-

75. E.g., GUTTMAN \& THOMPSON, supra note 16 , at 27 ("Constitutional democrats add another set of rights to those that have priority over the democratic process, rights whose primary purposes is to produce justified outcomes."). 
ist only when something that is both desirable and achievable nonetheless remains undone.

Other alternatives to deliberative democracy focus on ensuring that the institutions of government are not closed to any eligible political participants, and that one citizen's participation is no less effective than another's. These approaches are sometimes called process-based, proceduralist, or democracyreinforcing because they downplay the importance of regulating political outputs except insofar as those outputs attempt to distort the processes of majority rule. ${ }^{76}$ Like constitutionalism, they also advance an ideal of politics that seems capable of actually being achieved, depending upon the specific meaning one gives to openness and effectiveness.

Deliberative democracy endorses a number of constitutionalism's constraints on majority outcomes, as well as proceduralism's efforts to ensure equal access to democratic participation. In the case of deliberative democracy, however, these constraints are generated by a normative structuring of the decision processes politics that is much more elaborate and demanding than either constitutionalism or proceduralism. Deliberative democracy aspires to structure the practices of "middle democracy"- "the ongoing practices of everyday politics." Although deliberative democracy might thus be termed process-based, its ambition to change the internal workings of daily political discourse by orchestrating the myriad activities that are internal to political institutions moves it into a different category. Once equal access and effectiveness have been met, process-based theories treat majority decision-making as a black box, accepting almost any result as legitimate. In contrast, deliberative democracy micromanages what goes on inside the box, demanding that debate, dialogue, and decision-making satisfy deliberative norms. Indeed, the demands of deliberation placed on middle democracy are so onerous that there are good reasons to believe they cannot be achieved by human society as currently constituted ${ }^{78}$-as deliberativists themselves concede. ${ }^{79}$

The fact that no democracy could ever achieve all of deliberation's demands prompts a question as to how, if at all, deliberative democracy evaluates the many democratic structures that might be achievable, when all of them fail the ultimate deliberative test. What, in other words, is its approach to evaluating second best systems? Related to this question is another: If the ideal described by deliberative democracy is not a realistic goal, what are deliberative democracy's realistic prescriptions for flawed democracies-what, practically speaking, should those of us interested in improving democracies be trying to do?

76. John Hart Ely's theory is among the most prominent. See JOHN HART ELY, DEMOCRACY AND DISTRUST (1981).

77. GutMAnN \& ThOMPSON, supra note 16 , at 40.

78. See supra text accompanying notes $94-110$.

79. E.g., GUTMANN \& THOMPSON, supra note 16, at 357 ("To be sure, [deliberative democracy's] highest ideals place demands that actual politics may never fulfill."); Postema, supra note 34, at 356 (describing public deliberation as a regulative ideal); id. at 371 ("We are typically forced by circumstances to make decisions ... on the basis of uncompleted deliberation."). 
One possible answer to the first question is that deliberative democracy has no theory of second best. Hence, decisions made under conditions short of deliberation are neither justified nor legitimate according to the norms of that theory. At best, deliberative democracy would just have nothing to say when it comes to comparative assessments of any present or realistically possible democracy, and would simply be agnostic about whether some other democratic theory-one presumably inferior to deliberative democracy itself-provides suitable measures for such an assessment. At worst, deliberative democracy would say that no system of government can be justified or legitimate according to the best theory of democracy-deliberative theory-and, hence, the only recourse is to abandon democratic forms in favor of other approaches to governance, ones that do not depend upon the idea of rule by the people for their justification and legitimacy.

No deliberativist I know ends up endorsing either of these conclusions. Notwithstanding the inability of any actual democracy to meet the demands of deliberation, Gutmann and Thompson think that flawed democracies can make decisions that are legitimate and, to a degree, justifiable. They claim that a "decision is legitimate if it is made according to proper political procedures, but the extent to which it is morally justifiable-how right or just it is-depends substantially on the extent to which it is made and enacted deliberatively." ${ }^{\circ 0}$ Gutmann and Thompson do not define "proper political procedures," but by contrasting such procedures with the conditions of deliberation, they seem to announce that, even if the conditions of deliberation are not achievable, compliance with proper political procedures might be. For instance, proper political procedures could mean something no more demanding than the procedures that are regularly followed in making decisions. Whether this or something more exacting is what they have in mind, understanding proper political procedures to be achievable makes it possible for non-deliberative democratic decisions nevertheless to be legitimate.

While legitimacy can be achieved without full compliance with deliberation's demands, justification cannot-at least full justification cannot. Because justification depends upon meeting deliberation's demands, and those demands can never be met, no decision can be fully justified. The passage quoted, however, does not paint a hopeless picture for justification, because it treats justification as a matter of degree, of more or less. How much more or less-"how right or just"- depends on "the extent to which it is made and enacted deliberatively." In spatial terms, the image is of a continuum along which the justifiability of a decision correlates with "the extent to which it is made" deliberatively. "The closer the real conditions that precede the voting, and the conduct that follows it, approximate the ideal conditions of [deliberation], the stronger the moral justification for the policies that are voted into law." ${ }^{81}$

80. Gutmann \& Thompson, Why Deliberative Democracy is Different, 17 SOC. PHIL. \& POL'Y 161, 179 (2000).

81. Id. at 179 . 
This interpretation of justifiability supplies a standard for comparing any two decision processes. By determining which of two procedures more closely approximates the deliberative ideal, one can determine which of the two is more justifiable..$^{82}$ This standard fails to distinguish justifiable from unjustifiable decisions, but it does reveal something about Gutmann and Thompson's understanding of the dividing line between justifiable and unjustifiable decisions. ${ }^{83}$ If we imagined a continuum in which decisions were ranked based on their deliberativeness, with points further right being more deliberate than points to their left, under Gutmann and Thompson's theory the dividing point between justification and lack of justification must be to the left of the right pole. Otherwise, it would be wrong to speak of the "extent" of justifiability, as Gutmann and Thompson do. Assume there were no space between the point at which partial compliance with the demands of deliberation produced a partially justified decision and the right pole representing full deliberative compliance. In that case, decisions could be in only one of two states: either they would be at the right pole, perfectly compliant and hence justified, or they would be to the left of it, and unjustified. But Gutmann and Thompson speak of a third state: more or less justified. To make sense of the passage, then, the deliberation/justification continuum needs three regions. Unjustified decisions start at the left pole and continue up to some point intermediate between the poles, where a region of partial and ascending justification begins. The right pole itself is the third region, full justification, one that no realistic form of democratic decision-making will reach.

This imagery of moving from less to more justified as one moves left to right within the middle region hints at an answer to the question of what deliberative democratic theory demands of existing democracies. It demands ongoing efforts to keep moving farther and farther to the right. The conditions of deliberation function as a regulative ideal, which democracies should always strive to approximate. ${ }^{84}$ "We can demand real social and political institutions to approximate" the ideal. ${ }^{85}$ Deliberative conditions should be satisfied "as far as possible." ${ }^{\prime 6}$ If institutions are not currently conducive to deliberation, "reci-

82. Actually scaling the degree of compliance with deliberation's conditions presents substantial conceptual problems, but they are not material to the current topic.

83. There are passages in DEMOCRACY AND DISAGREEMENT that are suggestive of criteria for unjustifiability. The authors assert for instance, that "in the absence of robust deliberation in democracy, citizens cannot even provisionally justify many controversial procedures and constitutional rights to one another." GUTMANN \& THOMPSON, supra note 16, at 18. Most often, though, they speak in terms of relative justifiability and relative compliance with the conditions of deliberation. Id.

84. Gerald Postema sets consensus as the regulative ideal, but Gutmann and Thompson posit as society's goal the entire panoply of deliberative requirements, including mutual accommodation when consensus finding fails. Compare Postema, supra note 34, at 356 with GUTMANN \& THOMPSON, supra note 16 , at 13 .

85. Postema, supra note 34 , at 360.

86. Gutmann \& Thompson, supra note 16, at 13. See also Gutmann \& Thompson, Why Deliberative Democracy is Different, supra note 80, at 175 ("Deliberative democrats . . are committed, and not just provisionally, to mutually justifiable ways of judging the distribution of power."). 
procity prescribes institutional change. ${ }^{\not 87}$ If deliberative institutions exist, but individuals do not employ them, then individuals should be urged to comply with the conditions of deliberation more fully in order to achieve closer approximation and, hence, a better system of governance. ${ }^{88}$ Deliberative democracy urges that we should press forward along the deliberative continuum, always striving to move from less deliberation to more. ${ }^{89}$

This picture of deliberative democracy must confront a serious issue, one that it shares with any theory committed to single, unattainable normative objective. Pursuing deliberative democracy's objective of more and more deliberation will consume more and more of society's resources, drawing those resources away from the pursuit of other values that are themselves highly valued. Because deliberation cannot ever be fully achieved, the call to pursue ever more deliberative decision-making processes will be relentless. How does deliberative democracy justify the demand it places on citizens? To date, the deliberative literature fails to engage with, let alone justify, the costs of deliberation.

An initial reason to question investing in deliberation is that imperfect deliberation-the only kind there will ever be-can backfire. One of the supposed advantages of deliberation is that it improves people's knowledge, thereby leading to better decisions. Unfortunately, all deliberation can guarantee is an increase in people's information, which is not the same thing as better decisions. Knowledge is that subset of information that produces better decisions. ${ }^{90}$ Information, on the other hand, is a broader category, encompassing "facts" that are bad or false, as well as good or true. ${ }^{11}$ If people cannot distinguish between bad or false information acquired through deliberation and knowledge acquired through deliberation, then increased deliberation can lead to poorer decisions. Even acquiring information that is simply neutral with respect to improving decisions by leaving predictions just as accurate, no more nor less, than they were before the information was acquired, wastes the resources expended to acquire it. To the extent that deliberation contributes information but not knowledge, more deliberation will leave us worse off than we

87. GUTMANN \& THOMPSON, supra note 16 , at 73.

88. Gutmann \& Thompson, Why Deliberative Democracy is Different, supra note 80, at 179.

89. Whether more deliberation always equates with more moral justification has been challenged, but exploring that line of inquiry is beyond the scope of this article. See, e.g., Lynn M. Sanders, Against Deliberation, 25 POL. THEORY 347, 369-70 (1997) ("Deliberation ... has pernicious consequences, to the extent that it is distracting from more basic problems of inclusion and mutual recognition, and to the extent that it favors a form of expression and discourse that makes it likely that the talk of an identifiable and privileged sector of the American public will dominate public dialogue.").

90. Arthur Lupia \& MAthew D. MCCubbins, The Democratic Dilemma 24-25 (1998) ("We define knowledge as the ability to make accurate predictions. ... Note that having information and having knowledge are not the same thing. Knowledge is the ability to make accurate predictions; information is data. Knowledge requires information ... [b]y contrast, you can know a long list of facts and fail to put them together in a way that allows you to make accurate predictions. Thus, although you cannot have knowledge without having information, you can have information without having knowledge.").

91. Id. at 29 ("[I]nformation can actually be harmful . . information is valuable only when it prevents costly mistakes.”). 
were before, whether by decreasing the quality of decisions or consuming resources without any deliberative return.

Here are two examples of deliberative exchanges of information that can lead to costly mistakes. First, information about the (ill-founded) opinion of others can sometimes trigger an (unreliable) information cascade. Such cascades occur when information regarding the perceptions or beliefs of others causes individuals to adopt the same perceptions or beliefs, thereby "trigger[ing] chains of individual responses that make these perceptions appear increasingly plausible through their rising availability in public discourse," even though nothing has happened to change an anticipated event's probabilities. ${ }^{92}$ Information exchanged in a deliberative process can also lead to group polarization, due to a propensity of like-minded people sometimes to gravitate toward the extremes in a discussion instead of toward the median. Group polarization presents the possibility that "like-minded people engaged in discussion with one another may lead each other in the direction of error and falsehood." ${ }^{93}$ Still more deliberation might cure deliberative problems such as these, but the fact that pure deliberation will seldom if ever be achieved means that the risk of such deliberative errors going uncured is real.

These costs of error and wasted resources are real, but they pale in comparison to the direct opportunity costs of deliberation. So long as people continue to disagree about public policies, deliberation will consume large quantities of time and resources. Under deliberative theory, ideas about public policies are not simply to be presented publicly, they are to be tested in the public forum. People must present arguments, listen to counter-arguments and claims, and marshal and transmit rebuttal arguments in the public arena. Deliberators on controversial topics must recognize that any dialogic engagement reaches conclusions that are only tentative and provisional. ${ }^{94}$ For such topics, the deliberative norm is not a single deliberation, but a series of "reiterated deliberations." The demands of deliberation extend to all of the significant policy decisions a society has to make. Given the scope of governmental authority and the manifold ways questions can be formulated, refined, and subdivided, the number of such decisions will be practically limitless. Deliberative fora and institutions must also be designed for all levels of government-federal, state, and local. Deliberative agendas will have to be constructed somehow, because it will prove impossible to deliberate on every decision simultaneously. Agendasetting itself will have to be the subject of deliberation. Tough issues-the subjects of reiterated deliberation-will be queuing up to re-enter the agenda as soon as they are tentatively and provisionally resolved, competing for agenda space with other issues.

92. Timur Kuran \& Cass R. Sunstein, Availability Cascades and Risk Regulation, 51 STAN. L. REV. 683, 685 (1999). (2001).

93. Cass R. Sunstein, Deliberative Trouble?: Why Groups Go To Extremes, 110 YALE L.J. 71, 118

94. Gutmann \& Thompson, Why Deliberative Democracy is Different, supra note 80, at 176.

95. GUTMANN \& THOMPSON, supra note 16 , at 144. 
The law, upon which deliberative theory draws for its conceptual model of politics, can provide some insights into the resource-consumptive nature of the deliberation the theory wants to infuse into political decision-making. What we learn from law is not terribly encouraging for deliberative politics, because legal decision-making is enormously resource-consumptive. The Supreme Court, considered the exemplar of public deliberation for a number of deliberativists, currently decides only about eighty cases a year. To handle this workload, each of the nine justices employs four full-time clerks, who are supported by secretaries, docket-room personnel, library staff, and other employees many times more numerous. Doing the work involved in selecting and deciding the eighty cases is a full-time job for the entire crowd. The litigants that advance the arguments which form the backbone of the Court's deliberations have themselves spent thousands and sometimes tens of thousands of person-hours bringing their cases forward. Significant as they are, these Supreme Court costs are but the tip of the iceberg for the legal system as a whole.

Indeed, many legal disputes are scarcely deliberated at all. Sometimes one side stops deliberating precisely because she no longer thinks the expenditure of resources can be justified. Sometimes the appellate court concludes that the case is not worth its time and dismisses the appeal summarily. Even more bracing for the ambitions of deliberative theory, many more disputes are not deliberated at all. The criminal justice system would grind to a halt if every prosecution proceeded to trial. Ninety to ninety-five percent of civil cases settle before they get to trial. (Settlements short of trial might be deliberatively justifiable, but only if the parties involved have fully examined each other's arguments, and the settlement does not reflect the influence of economic pressures, in at least a preliminary manner, but these conditions are often unmet.)

Translating knowledge about the time and resource implications of legal deliberation to the political arena cannot be done with any precision, but several features of the context within which political deliberation takes place suggest it could be even more resource-consumptive than legal deliberation. For one thing, as costly as it is, legal deliberation (and settlements) benefits from the fact that law narrows the scope of the issues involved in a case and the parties relevant to the dispute's resolution. The paradigm lawsuit is bipolar and raises a small number of contested issues. In contrast, most political disputes are polycentric, implicating many parties and many issues, which criss-cross among the parties in different ways. This makes political settlements that are acceptable on deliberative grounds harder to achieve than legal settlements, and it makes full deliberations complicated and time-consuming. On each and every issue, arguments will have to be marshaled and counter-arguments responded to in a process that gives every deliberator ample opportunity to present and listen to views.

The foregoing suggests that individuals would have to invest massive resources to satisfy the demands of deliberation, yet no deliberative theorist has paid any attention to the costs and tradeoffs involved. The theory's oblivious- 
ness to costs seems particularly odd given the spatial imagery that is implicit in the theory. Progress in democratic justifiability is conceptualized as coming in degrees, step by step, as society engages in more and more deliberation. ${ }^{96}$ That imagery almost unavoidably invites one to ask if the next step along the continuum is worth its costs. After all, what is at stake within the middle region is not the dramatic distinction between unjustified and justified decisions, but rather the more quotidian difference between a partially justified decision and a more partially justified one, even one that is perhaps merely a small bit more justified than the first. ${ }^{97}$ This marginal thinking about gains invites, it seems to me, similar marginal thinking about costs-and about whether one is worth the other.

Once one acknowledges the presence and relevance of costs to deliberation, whether further moves along the continuum are themselves justifiable will depend upon one's theory of value. One set of perspectives would approach such matters through a utilitarian lens, looking to individual and aggregate utility functions as their guide. Within such a paradigm, whether deliberation ought to be pursued depends upon whether it is utility-maximizing. Gutmann and Thompson, however, think utilitarianism is inadequate as a theory of value. ${ }^{98}$ Even if one is not utility-maximizing, individuals who are being asked to deliberate confront some alternative and valued pursuits that cannot just be ignored.

Private pursuits, including those associated with family, work, and leisure, will compete for the resources of deliberative citizens. We live in a time in which human flourishing is intimately associated with activities of private life, including family, relationships, career, and the pursuit of life projects. The value in these aspects of ordinary life constitutes one of the hallmarks of modernity. ${ }^{99}$ Modernity is thus distinguishable from earlier traditions such as Aristotelianism, where participation as a citizen in the polity occupied a hierarchically superior moral position to the activities of ordinary life. In contrast, modernity has experienced a transition "which upsets [this Aristotelian hierarchy], which displaces the locus of the good life from some special range of higher activities and places it within 'life' itself. The full human life is now defined in terms of labour and production, on the one hand, and marriage and family life, on the other. At the same time, the previous 'higher' activities come under vigorous criticism." ${ }^{100}$

Elevation of the values of ordinary life has substantive political implications, such as underwriting a heightened sense of the importance of justice and freedom, conditions of social life vital to the full enjoyment of the ordinary. It also

96. See supra text accompanying notes 80-89.

97. The dramatic improvement in going from unjustified to justified might deflect attention from the price to be paid for the improvement, but in principle it would not remove the question whether that move were worth the cost.

98. GUTMANN \& THOMPSON, supra note 16, at 165-98.

99. See CHARles TAYlor, Sources OF THE SElF 211-13 (1989) (describing the "ordinary life" as "those aspects of human life concerned with production and reproduction, that is, labour, the making of the things needed for life, and our life as sexual beings, including marriage and the family").

100. Id. at 213 . 
has implications for political process, by making it impossible to take for granted that the demands of public life ought invariably to take precedence over the private. ${ }^{101}$ At some point well short of all public decisions being fully deliberated, the pursuit of the private may justifiably take precedence over public deliberation.

Even if deliberativists could defend the view that citizens ought to make all the sacrifices necessary to keep moving along the deliberative continuum toward the ideal-and I do not know how that argument would proceed-they would face a further formidable obstacle. Deliberativists must persuade and thereby motivate citizens themselves to undertake the demands of deliberation. It is not enough to win an argument in the graduate seminar room-it also must be won in kitchens, soccer fields, and workplaces.

One version of this point is quite familiar to anyone with a passing acquaintance with law and economics or positive political theory: Any theory of human action that involves choice must take into account the incentives and disincentives associated with those choices. The point was driven home in an article which proved seminal in both of these sub-disciplines. In a 1971 essay, George Stigler noted the then-prevalent tendency of students of regulatory policy to analyze the efficiency properties of regulated markets, to make recommendations for regulatory reform, and then to decry the failure of the regulators to implement their recommendations. ${ }^{102}$ Stigler argued that this "idealistic view" of "preach[ing] to the commissioners or to the people who appoint the commissioners" is bound to fail to produce the desired results, because it ignores "the basic logic of political life." spond to criticisms of its allegedly pro-railroad policies than is the Great Atlantic and Pacific Tea Company likely to respond to criticism that it sells groceries. $^{104}$ In both situations, what we observe are individuals responding to incentives and pursuing the interests that motivate them most. Regulators respond to pressures and incentives offered by members of an industry that supports policies favoring industry over the consumer, rather than to protestations about the ideal of efficiency, because there are neither pressures nor incentives from the efficiency corner comparable to those offered up by industry.

101. Not everyone applauds the displacement of the Aristotelianism system. Modern human beings have been described as "depoliticized ... . beings who are totally immersed in private concerns, [devoted to a life of] lavish consumption." The result is "stunted individuals who have embraced lives emptied of political responsibility [in which] the human ties that supply life with a bottomless fund of interpretable experience [have been] deliberately snapped." SHELDON S. WOLIN, TOCQUEVILLE BETWEEN Two Worlds: THE MAKING OF A PoliticAl AND TheORETICAl Life (2001), quoted in Stephen Holmes, Both Sides Now, The New RePublic, Mar. 4 \& 11, 2002, at 31, 32. It is also fair to note, however, that "[b]y asserting . . that a political utopia has been 'lost,' Wolin might make readers believe that it once existed. But he will not tell us when and where...." Holmes, supra, at 32.

102. George Stigler, The Theory of Economic Regulation, 1 BELL J. OF ECON. \& MGMT. SCI. 1 (1971), reprinted in CHICAGO STUDIES IN POLITICAL ECONOMY 209, 225-28 (George Stigler ed., 1988).

103. Id.

104. Id. at 228 . 
In light of the success of law and economics and positive political theory, it perhaps just states the obvious to point out that incentives affect the likelihood that the demands of deliberation can be met. Yet the notion that individuals face conflicting values that will draw them away from deliberative pursuits has further, less obvious significance as well. Political theory aimed at articulating ideals that we should try to implement in our actual practice must necessarily persuade in theory and in practice. ${ }^{105}$ It must persuade that the type of society it contemplates embodies attractive features, giving adequate attention to justice, equality, human freedom, and the like, and promising an environment conducive to human flourishing. Beyond this, it must also persuade the people whose voluntary behavior is necessary to establish and perpetuate the institutions and roles contemplated by the theory. What can be missed is that these two moments of persuasion interact. "If real people find it psychologically impossible to live as the theory requires, or to adopt the relevant institutions, that should carry some weight against the ideal." ${ }^{106}$ Victory in kitchens, soccer fields and workplaces affects victory in the graduate seminar, because the feasibility of an ideal is a consideration in evaluating its merits for real people, as opposed to an ideal for materially different beings. Political theories that try to perform a prescriptive task rather than a purely idealistic or purely descriptive task bear the burden of convincing us that what they want done is sufficiently within the grasp of the people who must do it that it, or something approximating it, might actually be possible. In this approach, the reactions of individuals to the call to action has implications for theory as well as for practice.

In the case of individuals choosing between deliberative and private pursuits, while there is good evidence that citizens will invest some resources in participating in public affairs, that evidence comes nowhere near suggesting they will invest resources of the magnitude deliberative theory demands. ${ }^{107}$ The behavior necessary to satisfy the demands of deliberation stands quite outside anything that can be achieved, just as deliberative theorists concede. While conceding this reality, though, they ignore its implications. It is worth a moment to reflect on both the reality and the implications.

Consider that politics as currently practiced in the United States is already vibrant with opportunities to participate in events that contribute to deliberative objectives. For instance, my church recently held an information and discussion session on an upcoming county bond referendum, which would provide monies for necessary capital improvements to the city's school system. My congregation is fortunate to include one of the individuals elected to our Board of Education. She gave an extremely knowledgeable and informed presentation, including a fair representation of the reasons some people were opposed to the measure. Of a congregation of 250 , twelve people attended.

105. Thomas Nagel, What Makes a Political Theory Utopian?, 56 SOC. RES. 903, 903-04 (1989).

106. Id. at 904 .

107. See supra notes $109-111$ and accompanying text. 
And so it goes throughout political life. We are awash in public meetings and other opportunities to discuss public issues, but the ample opportunities to engage in deliberative activities are poorly attended. Even if they were better attended, engaging in such activities would only accomplish part of the deliberation upon which deliberativists insist. Deliberative citizens have an obligation to carry their views to other citizens and to allow them to be tested by listening and being receptive to counter-arguments and evidence. The incentives to participate fully in such experiences are not great.

Deliberativists who hold onto the project of turning politics into law would gain much by turning again to the legal model as a source of information about how to achieve the demands of deliberation. Importantly, the dissimilarities between the two decision-making environments create enormously different incentives. The classical Anglo-Saxon model of the legal system unites desired behavior and the motivation to invest in that behavior much more effectively than politics does. As already noted, the adversary system separates the role of judge and advocate. It then pays individuals to make judging their job, which they retain by avoiding obvious conflicts of interest and displays of bias, and in which they gain recognition and peer respect by treating litigants with respect and considering their arguments attentively. The system pays others to be advocates, tying their remuneration and success to hard work in advancing the best arguments possible for their clients. For neither judge nor advocate is the alignment of desired function and incentive perfect, but it is an alignment enormously superior to the alignment of the demands of deliberation in political life to the various and diverse incentives given citizens.

This argument does not rely upon any of the gloomy conclusions reached by rational actor models of behavior, which presume individuals to be motivated solely by narrow self-interest. Much empirical research has shown that it is more realistic to posit that individuals respond to incentives and pressures based on a variety of values, including self-regard, regard for others, and concern for decision-making processes. ${ }^{108}$ Combined with innovative theorizing, this research has produced improvements and revisions to narrow rational actor models. Even under such improved models, however, the result of the analysis does not change. Rather than providing a basis to think that people could come to desire the rewards of full deliberation more than any others, these models shed further light on why total commitment to public pursuits is completely unlikely.

One example of an improved model is Howard Margolis' dual utility approach, in which human beings have preferences both for partial interests and

108. Students of behavioral economics have taken the lead in empirical work showing the influences of values other than purely self-regarding ones. For introductions into the literature, see John O. Ledyard, Public Goods: A Survey of Experimental Research, in THE HANDBOOK OF EXPERIMENTAL ECONOMICS 111 (John A. Kagel \& Alvin E. Roth eds., 1995); Ernst Fehr \& Simon Gachter, Fairness and Retaliation: The Economics of Reciprocity, 14 J. ECON. PERSP. 159 (Summer 2000); Matthew Rabin, Incorporating Fairness into Game Theory and Economics, 89 AM. ECON. REV. 1291 (1993). 
public interests. ${ }^{109}$ Margolis hypothesizes that the trade-offs between these two sets of preferences are governed by two plausible rules. The first is that, ceteris paribus, the more social utility that can be acquired with a marginal dollar compared to the private utility that could be gained with that dollar, the more likely someone is to engage in public interest behavior. Individuals, hence, are more likely to respond with public-regarding behavior when the private gain foregone is small relative to the public gain. This is the value ratio rule. The second rule is that, ceteris paribus, the larger the ratio of one's public interest spending already compared to one's private spending, the less likely the person is to engage in more public interest spending. Individuals who have already done a lot in the public sphere may conclude that they have done their fair share. This is the participation ratio rule. ${ }^{110}$

Margolis' two-utility theory suggests that individuals will engage in publicspirited behavior when they are asked to do just a few simple deeds, because the participation ratio for many people will then be low and the value ratio relatively high, in so far as they will not forego much private satisfaction if the deeds are simple. In this way, the model can explain why people vote, why they occasionally write to an elected official, and why they send modest amounts to political parties or interest groups. In this regard, the theory is an improvement over the standard rational actor models, which have difficulty explaining activities like voting in a straightforward way.

As public behavior becomes costly relative to private gains, and as the public forum asks for more and more resources, the participation ratio climbs and the value ratio falls. The result is less and less additional individual commitment to public-spirited acts. This combination-high participation ratio and low value ratio-characterizes the demands of deliberation. Even Margolis' more realistic and less gloomy model will predict that individuals will at some point choose not to commit further resources to deliberation. In the absence of some empirical evidence that demonstrates that people will engage in very costly public interest behavior of the sort deliberativists demand, on a regular basis, the burden would seem to be on deliberativists to demonstrate that what they advocate by way of deliberative activity is plausible in light of people's motivations, even assuming them to be partially public-regarding in nature.

The opportunity costs of deliberation have yet to be accounted for by deliberative theorists, and those costs alone undermine the attractiveness of the theory. In any situation of less-than-ideal conditions, furthermore, deliberative theory faces the further problem that deliberators would have to achieve a mental state quite different from the one with which we approach most informationgathering and processing situations_-and therefore quite difficult to achieve.

109. See, e.g., Howard Margolis, Selfishness, Altruism And Rationality: A TheOry of SOCIAL CHOICE (1984). Margolis's dual utility theory is summarized in Howard Margolis, Dual Utilities and Rational Choice, in BEYOND SELF-INTEREST 239 (Jane J. Mansbridge ed., 1990) [hereinafter Margolis, Dual Utlities].

110. Margolis, Dual Utilities, supra note 109, at 240. 
Deliberativists argue that the mutual respect we owe others who commit to the enterprise of finding shared ground for cooperation calls for the virtue of open-mindedness, a "disposition [that] maintains the possibility that citizens can be convinced of the moral merits of their adversaries' position." ficult disposition for any of us to achieve. Cognitive research suggests that human beings normally exhibit a good deal of "cognitive inertia" with respect to theories we hold about the world. A considerable body of work also reports a confirmation bias, a tendency to seek confirmatory rather than disconfirmatory information. ${ }^{112}$

Cognitive inertia and confirmation bias explain the observed tendency to sort out arguments and evidence so as to privilege those that confirm our present beliefs. The theory of motivated reasoning has been offered as a way to understand how this sorting out process works. The theory of motivated reasoning builds on the hypothesis that we formulate favorable or unfavorable judgments about objects of our attention that are subsequently stored in our memories as an evaluative or affective "tag." mechanism that brings thoughts into consideration also carries the affective coloration of these thoughts to mind." 114

This suggests that many of our reasoning activities are "hot"-influenced in important ways by the tags that accompany our beliefs. In particular, when someone has "a wish, desire, or preference that concerns the outcome of a given reasoning task," this motivation "may affect reasoning through reliance on a biased set of cognitive processes: strategies for accessing, constructing, and evaluating beliefs" by providing a "directional goal" for her reasoning processes. ${ }^{115}$ That directional goal influences the results of the reasoning process because at any one time we do not draw on our entire supply of beliefs, techniques, and rules. Instead, when confronted with a problem about which we wish to deliberate, we draw on a subset of them. ${ }^{116}$ "[P] rules on different occasions: they endorse different attitudes . . . express different self-concepts ... make different social judgments ... and use different statistical rules." ${ }^{117}$ Our directional goals are among the conditions that can influence the beliefs, rules, and evaluations that people employ and find persuasive. ${ }^{118}$

111. GUTMANN \& ThOMPSON, supra note 16 , at 83.

112. See David Good, Individuals, Interpersonal Relations, Trust, in TRUST (Diego Gambetta ed., 1988) (summarizing some of the significant studies).

113. See, e.g., Milton Lodge \& Charles Taber, Three Steps Toward a Theory of Motivated Reasoning, in ElEMENTS OF REASON: COGNITION, CHOICE AND THE BOUNDS OF RATIONALITY 183-86 (Arthur Lupia et al. eds., 2000) (describing theory of cognition in which all social concepts are effect-laden, and in which the effect associated with social concepts is "stored directly with the concept in long term memory").

114. Id. at 196.

115. Ziva Kunda, The Case for Motivated Reasoning, 108 PSYCH. BULL. 480, 480 (1990).

116. Id.

117. $I d$. at 483 .

118. Id. 
A growing body of evidence supports these conclusions. ${ }^{119}$ For instance, in one study, women who were heavy caffeine consumers were less convinced by the evidence in an article claiming that caffeine posed risks for women than were women who were low consumers of caffeine. ${ }^{120}$ Men, who had no directional goal with respect to the evaluation of the study, showed no such differential effects. ${ }^{121}$ Similarly, persons who endorsed the viewpoint that capital punishment deters crime were more likely to criticize a disconfirming study on the basis of such reasons as "insufficient sample size, nonrandom sample selection, or absence of control for important variables" than were those who already believed that capital punishment was not a deterrent. ${ }^{122}$ It seems that we "are more likely to arrive at those conclusions that [we] want to arrive at."123

This research has led some to conclude that we are "biased reasoners, finding it nearly impossible to evaluate any new information in an even-handed way." ${ }^{224}$ Even if this strongly worded conclusion overreaches, at the very least this research makes it clear that the open-mindedness deliberativists insist upon will not be easily achieved. Gutmann and Thompson are more alert to these difficulties internal to the way people reason than they are to the competing costs of engaging in deliberative activity. They note that maintaining an open mind when one already has convictions is a "delicate balance," and one that "is no doubt psychologically as well as intellectually demanding." ${ }^{125}$ Rather than wrestle with how these demands might be met, though, they simply urge that people should try to change the way they think to accommodate deliberation, because "the personal and political dangers of a simpler path . . . are greater." This hortatory claim, however, is remarkably similar to the exhortations of regulatory economists pre-Stigler. ${ }^{127}$ Simply telling individuals what they should do will have little impact on actual behavior until incentives and motivations are aligned with the better course of action. Cognitive research adds to the problems of deliberative theory by showing us how difficult human beings would find sustaining the kind of deliberative stance demanded. This only exacerbates the implausibility of coming close to satisfying the demands of deliberation.

The problem of countervailing costs poses a serious obstacle to the practical attainment of the deliberative ideal. That problem proves the undoing of deliberative democracy's theoretical project-losing the argument in kitchens, work

119. See ZIVA KUndA, Social COGNITION 212-35 (1999) (summarizing evidence for the superiority of motivated reasoning theory over a purely cognitive account of reasoning).

120. Ziva Kunda, Motivation and Inference: Self-serving Generation and Evaluation of Evidence, 53 J. PERSONALITY \& SOC. PSYCH. 636 (1987)

121. Id.

122. Kunda, The Case for Motivated Reasoning, supra note 115, at 490 (citing C.G. Lord et al., Biased Assimilation and Attitude Polarization: The Effects of Prior Theories on Subsequently Considered Evidence, 37 J. PERSONAliTY \& SOC. PSYCH. 2098 (1979)).

123. Id. at 495 .

124. Lodge \& Taber, supra note 113 , at 184 .

125. GUTMANN \& ThOMPSON, supra note 16 , at 84.

126. $I d$.

127. See supra notes $102-104$ and accompanying text. 
places, and soccer fields means it loses in the seminar room, too. We have been critiquing the ambition of deliberative theory to structure politics so that it resembles law. In that ambition, deliberative theory seeks to be for politics what politics, in turn, is for law. Law ultimately depends upon and is subordinate to politics in that political decisions establish or sustain the structure of law, which the legal system then applies to individual cases. ${ }^{128}$ The politics involved could be "higher lawmaking," characteristic of constitution-drafting and constitutional moments amending the fundamental law, or it could be normal lawmaking, characteristic of normal statutory enactment. In either case, politics makes vital decisions that are pre-legal, since decisions are prior to and significantly responsible for the structure that the law subsequently imposes.

Stanley Fish has described deliberative democracy's project as an attempt "to replace large P Politics-the clash between fundamentally incompatible visions and agendas-with small $\mathrm{p}$ politics - the adjustment through procedural rules of small differences within a field from which the large substantive differences have been banished." ${ }^{129}$ By reducing politics to law-like disputes within a field sharply structured by the demands of deliberation, deliberative theory wants legal theory to order politics in the same way that politics orders law. The problem is that theory qua theory does not and cannot have this relationship to politics. The structure that deliberativists seek to impose is one that can only be adopted by political actors as they engage in political practice. This is unlike the structure that politics imposes on the practice of law, where people engaged in legal practice come to it with its basic political structure in place. No institution or practice stands similarly prior to politics to impose the structure on politics that deliberativists seek. Deliberativists attempt to take out of political practice decisions that must necessarily be endogenous to that practice.

This endogeneity means that the foregoing assessment of the opportunity costs of deliberation, as well as their cognitive difficulties, ought ultimately to be injected directly into the political decision of whether to accept those constraints or not. Fish and others have asserted that members of society whose comprehensive world views, religiously grounded or otherwise, preclude them

128. This does not mean that law is completely subordinate to politics; law is best described as a quasi-autonomous practice. The interpretation and application of law cannot be completely controlled by the law giver. Still, a lot of law's structure resides in the "quasi" part of its quasi-autonomous status, and much of that content is placed there through the political process.

129. Stanley Fish, Mission Impossible: Settling the Just Bounds Between Church and State, 97 COLUM. L. REV. 2255, 2298-99 (1997). While Fish thinks this is a characteristic tendency of liberalism, Bonnie Honig sees it as a tendency of political theory in general. BONNIE HONIG, POLITICAL THEORY AND THE DISPLACEMENT OF POLITICS 3 (1993) ("[m]ost political theories are hostile to the disruptions of politics and assume that the task of political theory is ... to get politics ... over, and done with"). James Morone finds this desire to domesticate politics present in public attitudes throughout American history, including especially punctuated periods of political reform, such as the Progressive and New Deal eras, when hope abounds that reform will put our system of government on automatic pilot. JAMEs MORONE, THE DEMOCRATIC WISH 141 (1990) ("In either [the New Deal or Progressive] tradition, the ideal was public administration as a mechanistic force rather than as independent judgment ... New Deal Keynesianism relied on automatic formulas rather than discretionary 'political' choices. The impulse is deeply rooted in American political history. Across the generations of reform, we have seen the search for automatic politics and the suspicion of public officials who would think for themselves."). 
from accepting the constraints of deliberation would be justified in rejecting them. ${ }^{130}$ The arguments against the demands of deliberation advanced here appeal to a broader audience. They ought to count even among people who might otherwise be prepared to accept those constraints. The appeal of the argument that a person would be justified in stopping short of total, unyielding devotion to the deliberative ideal because of its costs and difficulties is one that an otherwise willing deliberator is fully equipped to appreciate. At no point in the argument does anything turn on sectarian or nonpublic beliefs, knowledge, or assumptions.

Were a group of citizens ever to gather in a deliberative frame of mind to consider whether to endorse the demands of deliberation, they ought to refuse once they came to understand those demands. A seminar room debate that attends to the fate of deliberation in kitchens, soccer fields, and workplaces ought to reject deliberation as an unyielding ideal. Deliberation defeats itself.

Specific deliberative practices in specific contexts may still be urged upon political actors. Specific decisions and decisional processes may still be criticized for failing to be sufficiently deliberative. If the foregoing is correct, however, the basis of this criticism cannot be the universal claim asserted by deliberative theorists that politics ought to be like law. Because the call completely to assimilate politics to law fails, it follows that politics continues to be partially non-deliberative, which means it continues to be influenced by partial interests but cannot properly be criticized on these grounds alone.

Politics will necessarily be more rough-and-tumble, and less orchestrated and structured, than the ideal. Because deliberative theory is motivationally implausible, individuals involved in politics as practiced will continue to reason non-deliberatively and decisions will be made through non-deliberative institutions. There is much more to know about how such reason and institutions operate, as well as about how one influences the other. ${ }^{131}$ Work that is practically valuable will be oriented to our better understanding of institutions, reasoning practices, and how the two interact, and then toward understanding how political decision-making might be improved. In neither case is the legal model going to provide a good universal ideal against which to judge progress.

IV

\section{POLITICAL DECISIONS, DELIBERATION AND PARTIAL INTERESTS}

President Bush's August 9, 2001, stem cell decision came after a process that included many elements deliberativists ought to applaud. In his prime-time address announcing the decision, President Bush said that he had consulted with "scientists, scholars, bio-ethicists, religious leaders, doctors, researchers, Mem-

130. See Fish, supra note 129, at 2287-93.

131. See, e.g., Elements of ReAson: COGnition, CHOICE AND the Bounds of Rationality (Arthur Lupia et al. eds., 2000). 
bers of Congress, my Cabinet, and my friends." ${ }^{132}$ With the possible exception of the religious leaders-about whom more will be said in a moment-this is a group of discussants that any deliberativist should approve. The prime-time address itself constituted a reasoned and articulated announcement and defense of the decision. The President, in effect, acknowledged the demands of reiterated deliberation by establishing a President's Council to "monitor stem cell research, to recommend appropriate guidelines and regulations, and to consider all of the medical and ethical ramifications of biomedical research." ${ }^{133}$ Based on these visible aspects of the stem cell decision-making process, deliberativists ought to be well disposed toward the President's decision.

Less visible aspects of the process may also have had attractive deliberative attributes. Of course, we cannot know the internal thought process the President employed in reaching his final judgment, but the result itself can be seen as the product of an effort to accommodate two irreconcilable positions based on mutual respect, just as deliberativists would urge. ${ }^{134}$ One position asserted that embryonic stem cell research ought to be completely prohibited because it produces incentives for embryos to be created for the purpose of farming their stem cells, which destroys the embryo. The other side advocated that such research holds the key to many significant medical breakthroughs and thus ought to be encouraged. President Bush made a decision that ignores neither side and his explanation treats both sides with respect. He decided that the government would fund research on embryonic stem cells, thereby providing for the possibility of medical breakthroughs based on such research, but only if the stem cell lines involved in that research were already in existence, thereby preventing the availability of federal monies from becoming an incentive for creation of stem cell lines from new embryos. ${ }^{135}$ The stem cell decision thus exhibits a good number of positive features when viewed in a deliberative light, which was to be expected by virtue of the fact that in advance of the decision the President and his advisors had stressed that the President would consult widely and be led by what science and ethics recommended. ${ }^{136}$

At the same time, other features of the stem cell decision illustrate how far from the deliberative ideal actual political decisions are, even when instigated and carried out under favorable deliberative conditions. Most prominently, it is obvious that citizens as a whole did a very poor job deliberating about the controversy, notwithstanding the fact that they seemed to be paying fair attention to it. ${ }^{137}$ Few knew the content of the President's decision. Only one in four

132. President George W. Bush, Address to the Nation on Stem Cell Research from Crawford, Texas (Aug. 9, 2001), available at 2001 WL 14297878.

133. Id.

134. See supra text accompanying notes 73-74 (discussing Gutmann and Thompson's injunction of accommodation based on mutual respect).

135. See Presidential Address, supra note 132.

136. See supra text accompanying notes $1-2$.

137. A poll taken in October 2001 found that $51 \%$ of those responding had followed the stem cell story closely. This compared to $30 \%$ who followed closely a federal court decision blocking the President's plan for prescription drug discount cards; $65 \%$ who followed closely stories on the economy and 
were able to identify the key feature of the decision, its limitation on federal funding to existing stem cell lines only. ${ }^{138}$ Ignorance about the decision was coupled with ignorance about the issues involved. On the eve of the President's decision, only a bare majority were able to state the main reason for the stem cell controversy. ${ }^{139}$ Confusion about the issues was as evident as ignorance of them. Fully $62 \%$ stated they agreed with President Bush's decision to limit federal support to existing cell lines, ${ }^{140}$ while $75 \%$ of the same survey sample also approved of "using destroyed embryos discarded from fertility clinics that no longer need them" for research on disease cures, a practice that the Bush policy prevents. ${ }^{141}$ Such was the lack of awareness about a public issue that had received fairly prominent news coverage, with nearly $80 \%$ of the public saying the issue was very important or fairly important to them. ${ }^{142}$

This pattern of responses is quite consistent with a public that was picking up information about the stem cell issue in a more or less casual way without sustained engagement with others on the issue. Still, people who have opinions on stem cell research must have acquired or developed their opinions in some fashion. It turns out that a plurality of those opposed to stem cell research relied upon their religious beliefs in forming those opinions, while only $3 \%$ of those who supported such research said religious beliefs were the most important influence on their views. ${ }^{143}$ Perhaps the approving citizens realized that the demands of deliberation required them to limit the grounds of their ultimate decision to publicly accessible reasons, avoiding private religious beliefs, but this seems quite doubtful. More likely, those citizens did not base their judgments on their religious beliefs because nothing in those beliefs strongly supported one outcome or the other.

the shrinking budget surplus; and 95\% who followed closely the World Trade Center and Pentagon attacks of September 11, 2001. Henry J. Kaiser Family Foundation, Health News Interest Index Poll, October 1-5, 2001, available at Westlaw POLL database, question id: USPSRA.01HNIOC R02A - R02I.

138. Twenty-eight percent knew this was part of the decision. Kaiser Poll, supra note 137, at question id: USPSRA.01HNIOC R03.

139. Fifty-one percent knew it was because human embryos are destroyed in the research process; $7 \%$ believed danger to the adult subjects in research trials was the reason; $9 \%$ thought insufficient money was the reason; and 33\% did not know. Henry J. Kaiser Family Foundation, Health News Interest Index Poll, August 2-5, 2001, available at Westlaw POLL database, question id: USPSRA.01HNIIA RO3.

140. In a Fox News opinion poll, $59 \%$ of those surveyed said they approved of the President's decision. Fox News, Opinion Dynamics Poll, August 22-23, 2001, available at Westlaw POLL database, question id: USODFOX.032401 R12. A Gallup Poll taken prior to the President's decision indicated that $54 \%$ of those surveyed believed the federal government should fund research on embryos from fertility clinics. Gallup Organization poll, July 10-11, 2001, available at Westlaw POLL database, question id: USGALLUP.01JUL10 R20.

141. IPSOS-Reid Poll, August 10-12, 2001, available at Westlaw POLL database, question id: USIPSOSR.081301 R1, R2.

142. Thirty-six percent responded "very important" and forty-two percent responded "somewhat important" in a Gallup poll taken just after the President's decision. Gallup Organization Poll, August 10-12, 2001, available at Westlaw POLL database, question id: USGALLUP.01AG10 R11.

143. ABC NEWS poll, June 20-24, 2001, available at Westlaw POLL database, question id: USABC.062601 R3A, R3B. 
Indeed, whatever the other deliberative virtues of the President's own decision, avoiding the invocation of religious beliefs was not one of them. The President did more than simply consult with religious leaders; he declared that his own religious beliefs directly "shaped" his final decision. ${ }^{144}$ This acknowledgment by the President greatly diminishes the deliberative credentials of the stem cell decision, because it strongly suggests, if not explicitly admits, that a type of reason that deliberative theory wants to block from determining public outcomes was in fact material to such an outcome.

At this point, it is clear that the public has a much more positive attitude toward the President's decision and puts much less stock in the pedigree of the President's reasons than a deliberative theorist does. A survey taken immediately after the President's speech probed the public's opinion as to the President's reasons for his decision. Concededly, the survey question tried to force the responses into one of two choices: respondents were asked whether the President's opinion came "mostly because of political reasons or mostly because of his deeply held beliefs." seems reasonable to believe that most of the respondents equated "political reasons" with electoral considerations. ${ }^{146}$ "Deeply held beliefs," on the other hand, could refer to religious or non-religious based comprehensive views. Given the choice as thus framed, 52\% thought political reasons exerted the greatest influence, while $36 \%$ thought deeply held beliefs did. ${ }^{147}$ If we allocated half of the latter response to deeply held religious beliefs, which seems a conservative estimate, then $70 \%$ of the survey respondents thought the President acted on reasons deliberative theory wants to disallow from any political influence. Notwithstanding, three out of five people approved of the decision. Indeed, by one means of reckoning, the decision was a perfect compromise- of those who disapproved of the decision, $40 \%$ thought it wrong because it allowed stem cell research while $46 \%$ disapproved because it restricted stem cell research. ${ }^{148}$ In short, at least $70 \%$ of one survey thought the President's decision was predicated on reasons deliberative theory thinks impermissible, and yet the decision garnered strong majority support and divided dissenters nearly down the middle.

From a practical perspective, the President's decision has much to be said for it, which is what popular reaction seem to affirm. The decision may need to be revisited if the restriction to existing stem cell lines proves too confining for effective medical research, but as a means of managing the issue-which often proves to be the objective of political decision-making-the decision deserves

144. "My position on these issues is shaped by deeply held beliefs. . . I . . . believe human life is a sacred gift from our Creator." Presidential Address, supra note 132.

145. Gallup Poll, supra note 142, at question id: USGALLUP.01AG10 R12.

146. See infra for a discussion of the widely held understanding of "politics" as referring to strategic calculations and behavior driven by electoral considerations.

147. Gallup Poll, supra note 142, at question id: USGALLUP.01AG10 R12.

148. Fox News Poll, supra note 140, at question id: USODFOX.032401 R13. 
the positive grade the public has given it notwithstanding the pedigree of its underlying rationale.

The public's reaction to the stem cell decision puts on the table deliberative democracy's core claim that political decisions ought to be made without reliance upon religiously based comprehensive views or the resort to partial interests. To conclude this paper, I suggest that deliberative theory claims too much here, just as it claims too much in asserting that we ought to strive for more and more law-like deliberation. Setting as a goal of politics the elimination of such values, interests, and reasons has the same motivational implausibility as the goal of engaging in more and more deliberation. Partial interests and comprehensive views can no more be blocked pre-politically than deliberation can be imposed pre-politically.

It is at least questionable whether the injunction against partial and comprehensive views satisfies deliberative theory's own ideal of mutual respect. Deliberativists claim that when partial interest advocacy is done openly, it is ineffective in any event. Public argument, it is said, necessarily forces one to articulate arguments based on public considerations. One reason that "members [of an assembly] appear hesitant to bring up self-interest and sometimes express disapproval when another member does," is that there is a social norm "that says that no one should take a position that cannot be justified in terms of the benefits to the collectivity." ${ }^{149}$ A second reason is strategic: "Vote for the bill because it will make me better off" is not an argument anticipated to pick up many votes. ${ }^{150}$ Our own sectarian comprehensive views are similarly not likely to be convincing to others; our private values do not provide reasons to others to act. Open advocacy of partial interest positions, therefore, is going to be rare. If that is so, however, and individuals nonetheless want to rely upon such reasons and views to explain why they support a particular outcome, it must be because these are their strongest convictions regarding the subject under discussion and they believe it very important to express them. One way to vindicate the value of mutual respect is to hear them out.

All in all, though, the problems raised by partial interests and comprehensive views do not tend to arise when they are expressly invoked, but rather when they operate behind the scenes as the "real" motives of political actors. A major source of cynicism toward public decision-making is the widespread belief that individuals advance arguments that they do not believe, depend upon principles whose implications they do not endorse, and mask the pursuit of selfinterest in hypocritical appeal to public values. ${ }^{151}$

The conclusion that partial interest is what really drives politics generates a cynical logic that can be seen everywhere in discourse about public life. It is the

149. Jon Elster, Deliberation \& Constitution Making, in Deliberative DeMOCRACY, supra note 20, at 97, 101 (quoting JAMES COLEMAN, THE FOUNDATIONS OF SOCIAL THEORY 393 (1990)).

150. James Fearon, Deliberation as Discussion, in DeliberATIVE DEMOCRACY, supra note 20, at 44, 54. The fact that even majorities seem required to justify their actions in public interest terms suggests that the strategic reason does need to be supplemented with the norm-based reason. Id.

151. Joseph N. CAPPElla \& KATHLEEn HALl JAMIESON, SPIRAL OF CYNICISM 17-37 (1997). 
logic that permits conservatives to attack civil rights and environmental organizations as just another set of special interests, and liberals to do the same with the National Rifle Association. It is the logic that enables television anchors, reporters, and pundits to treat strategy as reality, and policy arguments as veils to be pierced. It is the logic whereby both Jim Lehrer and Secretary Thompson saw immediately that endorsing the president's stem cell decision as political would have been a mere confession of what most talking heads believed: "political" is code for "self-interest," and of course the decision will be based on that. $^{152}$

Deliberative democracy's requirement of sincerity is designed to block such posturing by public actors. Unfortunately, what begins as an attempt to improve politics can end up perpetuating a cynical conception of it because actual politics will inevitably and justifiably fall far short of the ideal being espoused. It is undeniable that self-interest motivates the actions of many people in the public arena; true profiles in courage are few and far between. If the presence of a strong partial interest motivation under a public-interest cellophane wrapper suffices to disparage a public actor, few can escape disparagement.

Because political action is so resource-consumptive, investment in it is most likely when the marginal dollar produces gains on both an individual's private utility function and her social utility function. Then the incentives are better aligned. The public acts of citizens and public officials thus are often the product of mixed motives, when both partial interest and public interest point in the same direction. Members of Congress consider it a wonderful thing when expediency and principle come together. Both citizens and officials can to a considerable degree exercise control of their agendas. They will tend to gravitate toward mixed-motive activities, thereby making political activities more likely.

The public interest benefits from such mixed motives. ${ }^{153}$ The combination effect of mixed motives stimulates important public policy. Supporters of civil rights, for instance, can applaud the efforts of African-American leaders of the civil rights movement, even acknowledging that those leaders might have been significantly motivated by self-interest, because they benefited materially from the enactment of desirable legislation. ${ }^{154}$ The cause of protecting the environment in the early 1970s benefited from a self-interested contest between Richard Nixon and Edmund Muskie for the environmental vote. ${ }^{155}$ Tobacco companies have been successful in blocking legislation creating further regulations for their product.

Whether these examples of mixed motives appeal to you depends upon your assessment of the quality of the public policy produced. Perhaps you think that

152. See supra note 2 and accompanying text.

153. For an excellent statement of the benefits of interest group advocacy in American politics, see Peter H. Schuck, Against (and for) Madison: An Essay in Praise of Factions, 15 YALE L. \& POL'Y REV. 553 (1997).

154. See Schuck, supra note 153, at 553.

155. E. Donald Elliot et al., Toward a Theory of Statutory Evolution: The Federalization of Environmental Law, 1 J. L. ECON. \& ORG. 313 (1985). 
the civil rights movement has produced undesirable public preference programs for minority enterprise, or in college admissions, or that the environmental legislation passed in the competition between Nixon and Muskie was excessively expensive and in other ways unwise, or that it is poor public policy to continue to permit tobacco sales without further regulation. If these are your attitudes, you are much more likely to focus on the partial interest dimensions of the corresponding political decision. Indeed, think of your own examples of when partial interests seem to have controlled a political outcome and I believe you will find yourself bringing to mind examples of cases in which you disapproved of the policy result. The partial interest influence seems much more benign-it may even entirely recede from our view-when you support the policy result. Public policy dynamics have this chameleon-like character precisely because there are mixed motives involved in almost all public policy, so that you can almost always identify a group or individuals with partial interests on the winning side. The chameleon's color changes not because partial interest motives are uniformly objectionable, but rather because the policy context and result have changed. We react to an outcome we find unattractive and then look for the guilty party.

Deliberativists may say they have no difficulty with mixed motives so long as the public interest rationale offered is sincere and reflects a commitment to its general application in other circumstances. Even this, however, is a heroically stringent demand to place on all political actors. Very few of us have fully worked out comprehensive views such that we can honestly stipulate to the general application of every principle we advance. Public policy issues can invoke the application to specific decisions of many difficult high-order concepts, such as freedom, equality, security, justice, and autonomy. Even those who hold to well-developed and widely held ideologies, such as liberalism or neoconservatism, may resist such a stipulation. Liberalism and neoconservatism, as well as many other ideologies, cannot claim the perfect consistency required to commit to the generality standard. ${ }^{156}$

Furthermore, working out at a personal level views that satisfy the deliberative requirement of sincerity is another resource-consumptive step that individuals are unlikely to take. This does not mean that people are insincere, only that they have not yet attended to a more careful development of their views. Illustratively, Dennis Chong has found that people can express unqualified support for rights that reflect tolerance, such as an unqualified right of free speech, and subsequently also support denying individuals and groups those rights. ${ }^{157}$ This need not be an indication of insincere convictions, however. It could be that these answers reflect a consistently held commitment to a weak right, one

156. Melvin J. Hinich \& Michael C. Munger, Ideology And the Theory of Political CHOICE 15 (1996) (citing Robert Higgs, Crisis AND LEVIATHAN: CRITICAL EPISOdES IN THE GROWTH OF AMERICAN GOVERNMENT (1987)).

157. George Klosko, Democratic Procedures and Liberal Consensus 54 (2000) (summarizing Dennis Chong, How People Think, Reason and Feel About Rights and Liberties, 37 AM. J. POL. SCI. 867-99 (1993)). 
subject more easily to qualifications than a strong one. ${ }^{158}$ You might be able to tell which view an individual holds only after the fact, after she has been confronted with situations requiring subtle choices to be made.

There are circumstances in which even the bald assertions of partial interests seem justified. Suppose that after participating in a deliberative process you sincerely become convinced that one action is preferable to another, all things considered, under appropriate deliberative conditions. Nonetheless, the question is a close one because the causal relationship between the policy being proposed and the desired end result is poorly understood or subject to change by intervening events. It is also a policy whose heavy costs will be predominantly borne by you. You object to the policy on the grounds that you are unwilling to bear those costs to achieve a possible, but somewhat speculative, public result. Would deliberative democracy deny the legitimacy of your voting "no" on the proposal on the basis of its heavily disproportionate impact on you?

Here, too, deliberative democracy might contend that resistance to such decisions is consistent with the demands of deliberation. Your objection, a deliberative theorist might say, could be understood as acceptably reasoned, by treating it as an assertion that the policy is unfair to you, and then acknowledging that unfairness of this kind can be part of a comprehensive view that mutually committed individuals could find acceptable. Therefore, what might seem like an impermissible partial interest reason can be translated into an acceptable public reason.

This kind of reply risks injecting into deliberative democracy the kind of tautological quality to which rational-actor models are susceptible. Rationalactor models can attempt to explain behavior that runs counter to self-interest narrowly construed by adding additional arguments to the individual's utility function. For example, voting becomes rationally understandable because people experience pleasure from performing a civic duty. The counterpart tautology for deliberative democracy is to treat private-interest reasons as reasons predicated on a conception of fairness that makes objecting to the cost distribution of a policy a public reason. It is doubtful that deliberativists would want to make this move. If deliberative theorists did, however, then they ought also to be candid in acknowledging the legitimate role that private reasons can play in their conception of democracy.

\section{V}

\section{CONCLUSION}

If deliberativists would concede that public acts can justifiably rest on mixed motives, that they can be justified by claims that partial interests are being unfairly treated, that no fully worked out general theory of fairness needs to be available to those actors, and that non-deliberative modes of decision-making and reasoning are necessary parts of political life, all that would be left for me

158. Id. at 58 (developing the idea of weak and strong rights). 
to quarrel with is their rhetoric's unintended complicity in the downward spiral of cynicism toward government. Then again, if they would concede all this, they would perforce stop painting such an implausible picture of what politics might be, and they would stop borrowing from the model of law. They could then turn their attention to constructive pursuits. 